\title{
Talent Management, Knowledge Management and Health Officer Performance on Service Quality
}

\author{
Nasriani, Hasmin Tamsah, Purnomo Purnomo \\ Program Pascasarjana STIE Amkop Makassar, Indonesia \\ nasriani21@gmail.com, hasmintamsah@gmail.com,Purnomo_purnomo@gmail.com \\ Firman H, Yusriadi Yusriadi \\ Sekolah Tinggi Ilmu Administrasi Puangrimaggalatung, Makassar, Indonesia \\ firmanhamzah119@gmail.com, yusriadi.yusriadi@uqconnect.edu.au \\ Muhammad Hasyim \\ Cultural Sciences Faculty, Hasanuddin University, Indonesia \\ hasyimfrance@unhas.ac.id \\ Faradila Hasan \\ Faculty of Sharia, IAIN Manado, Indonesia \\ faradila.hasan@iain-manado.ac.id
}

\begin{abstract}
This study aims to elaborate and analyze the model to improve performance that can impact the service quality of health workers in the Central Mamuju Regency. The independent variables used are talent management and knowledge management, which are tested to improve performance and improve service quality. This research was conducted in 2 (two) public health centres, namely Durikumba Health Center and Lara Public Health Center, Karossa District, Central Mamuju Regency. The sampling technique used was accidental sampling. 70 of 74 officers filled out a complete and complete questionnaire at the Durikumba Health Center and 45 of 53 officers at the Lara Health Center. The total final sample obtained was 115 officers. This study uses a correlational design with a quantitative approach. Data collection techniques with questionnaires and data analysis used are path analysis with Amos ver.25 software. The research results among variables such as talent management, knowledge management, service quality, and performance comprehensively show talent management as a variable that impacts improving performance and quality in service. The talent capabilities possessed by officers will create better account and quality. Good. Health workers show this with different talents who can provide sound output because each officer can integrate their strengths and complement each other. While knowledge management is another independent variable that also affects the performance and quality of Health Centre services, knowledge of health workers, especially midwives and nurses, is a measure of success in terms of performance and service quality. Doctors demonstrate this too, midwives and nurses and other health workers in applying their knowledge and mastery of technology, thus enabling them to better understand up to date knowledge and information.
\end{abstract}

\section{Keywords:}

Talent management, knowledge management, service quality, performance

\section{Biographies}

Nasriani is a student at Magister Program of Economic Science of STIE AMKOP, Indonesia. Her areas of interest and research include social science and economic. She has published some articles in national journals.

Hasmin Tamsah is a lecturer at Economics Department of STIE AMKOP, Indonesia. His areas of interest and research include economic, management, management human resource. He has published some books and many articles in national and international journals. 
Purnomo Purnomo is a lecturer at Economics Department of STIE AMKOP, Indonesia. His areas of interest and research include economic, management, management human resource. He has published some books and many articles in national and international journals.

Firman $\mathbf{H}$ is a lecturer in the Department of Public Administration at Sekolah Tinggi Ilmu Administrasi Puangrimaggalatung, Indonesia. His research fields and interests include social science, political science, sociology, and public administration. As a lecturer, he has published several scientific articles in both national and international journals. Apart from that, he has also published several books. He is also active in several organizations such as ADPERTISI Indonesia, IAPA Indonesia, and the STIA PRIMA BONE Lecturer Forum Organization.

Yusriadi Yusriadi is a lecturer at Public Administration Department of Sekolah Tinggi Ilmu Administrasi Puangrimaggalatung, Indonesia and chancellor on Sekolah Tinggi Ilmu Hukum Pengayoman. His areas of interest and research include social science, political science, sociology, legal studies, and public administration. He has published some books and many articles in national and international journals. He is a reviewer and editor in some local and international journals.

Muhammad Hasyim is an Associate Professor, in Cultural Sciences Faculty, Hasanuddin University, Indonesia. Since 1994, he teaches courses in semiotics, cultural studies, and French. the field of research carried out is the study of media culture and tourism culture with a semiotic approach.

Faradila Hasan is a lecturer at the Faculty of Sharia, IAIN Manado. His areas of interest and research include Family Law, family psychology, Islamic Economics Law, and Islamic Studies. He graduated from S1 Islamic Economics Law and S2 Family Law, IAIN Mando. He has published several articles in national and international journals. He is a member of the Indonesian Journal Volunteer, Fatayat NU North Sulawesi, and the Indonesian Ulema Council of North Sulawesi. 